\title{
自然観光地における観光者の環境負担金に対する支払意思と貢献実感の関係
}

\section{A study on the relationships between willingness to pay for environmental protection and tourist satisfaction}

武 正憲* 飯田 晶子**

Masanori TAKE Akiko IIDA

\begin{abstract}
The study aims to identify the relationship between willingness to pay for environmental protection and tourist satisfaction. The Republic of Palau is selected as a case study, where the national government collects the environmental protection fee of US\$30 from all the tourists and the state governments collect the entrance fee of US\$10 100 from the tourists who enter protected areas. A questionnaire survey was conducted on Japanese tourists. The study identified that more than $90 \%$ of the tourists had affirmative opinions on the payment and wanted to revisit even if they pay around US\$50 150. However, more than half of the tourists couldn't satisfy their payments, as they couldn't realize their contribution to the environmental protection and/or local society. The satisfaction level of the tourists who leaned the payment system by themselves through magazines or websites was higher than those of the others who were instructed by tour guides or who were not informed by anybody. These results indicate that if the governments improve the transparency of their use of money and notify the tourists of positive effects on local society and/or environmental protection, more tourists could realize their contribution and recognize their responsibility as beneficiaries.
\end{abstract}

Keywords: The Republic of Palau, Environmental protection fee, Entrance fee, Responsibility of beneficiaries, Willingness to Pay, Tourist satisfaction キーワード：パラオ共和国，環境税，入域料，受益者負担，支払意思，貢献実感

\section{1. はじめに}

自然観光資源の保全と利用の調和，および地域社会の持続のた めに，観光者にも責任ある観光（Responsible Tourism）の意識 と態度が求められている。その具体的方策の一つとして，観光者 (二受益者) が自然観光資源を保全する費用を負担する環境負担 金制度がある。

我が国では, 2014 年 6 月に通称「地域自然資産法」(正式名称：

「地域自然資産区域における自然環境の保全及び持続可能な利用 の推進に関する法律」）が成立した。これにより, 都道府県や地方 自治体が入域料の徵収やトラス卜事業の展開を通して, 自発的に 資金調達することが可能となった 1 )。

特に，富士山で「富士山保全協力金」の徵収が実施されるよう になってからは，その具体的な効果に対する検討が注目されてい る 2)。その中で，1,000 円という低額の環境負担金では，自然観 光資源を保全するための費用を十分に賄えないことや，観光者数 の抑止効果はあまり期待できないことが指摘されている3)

また，保全協力金の試験導入前の支払い意向と，導入後の実際 の支払い実績に大きく差があり，自治体が当初想定していた費用 が徵収できていないことが指摘されている 4)。すなわち, 自治体 が，環境負担金の導入前から，適正な金額などの条件を十分に検 討することや，観光者の環境負担金に対する意識や態度を把握す ることには限界がある。

また，我が国でこれまで導入された環境負担金は 100 円から 1,000 円程度 2) と低額であるため, それ以上の環境負担金に対す る意識や態度を把握するためには，トラベルコスト法やCVM な じを用いた仮想的な検討を行うことしかできず，実際に支払った 場合の意識や態度を理解することは困難であった。しかし，自然 観光資源の保全を十分に行なうためには，ある程度高額な環境負 担金の支払いに対する意識や態度を把握することが不可欠である。 さらに，観光者に環境負担金の支払いに対する貢献実感が伴わ ない場合には，制度への不満が増加寸ると考えられ，継続的に環
境負担金を徵収することが困難と考えられる。すなわち，観光者 が支払いに対する肯定的な意識を持ち，かつ支払いに対して貢献 実感を得ることが，自然観光資源の保全と利用の調和をはかるた めに重要な点であると考えられる。

そこで本研究では，日本人観光客が多く来訪し，既に環境負担 金制度を実施しているパラオ共和国（以下，パラオ）を事例に， 来訪する日本人観光者の環境負担金に対寸る支払意思とその支払 に対する貢献実感との関係を明らかにすることを目的とする。

\section{2. 研究方法}

\section{(1) 調査地概要}

パラオは, 人口約 1.7 万人 (2012 年現在) ${ }^{5}$ ), 面積 $456 \mathrm{~km}^{2}$, 16 の州より構成される島嶼国である。生物多様性豊かな地域であ り, 自然観光地として, 中でも世界有数のダイビングの目的地と して知られる。2012 年には「ロックアイランド群と南ラグーン」 が世界複合遺産として登録されている。

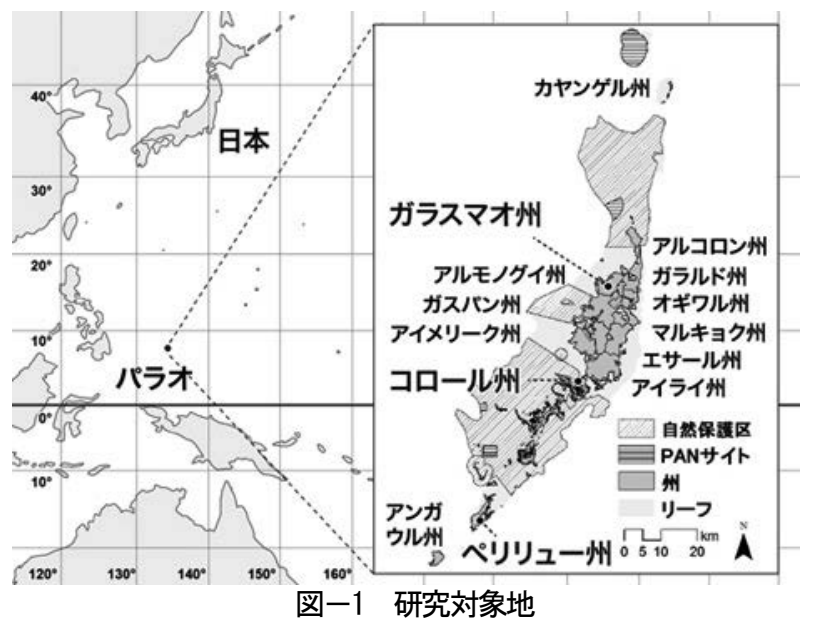

*筑波大学芸術系林東京大学大学院工学系研究科 


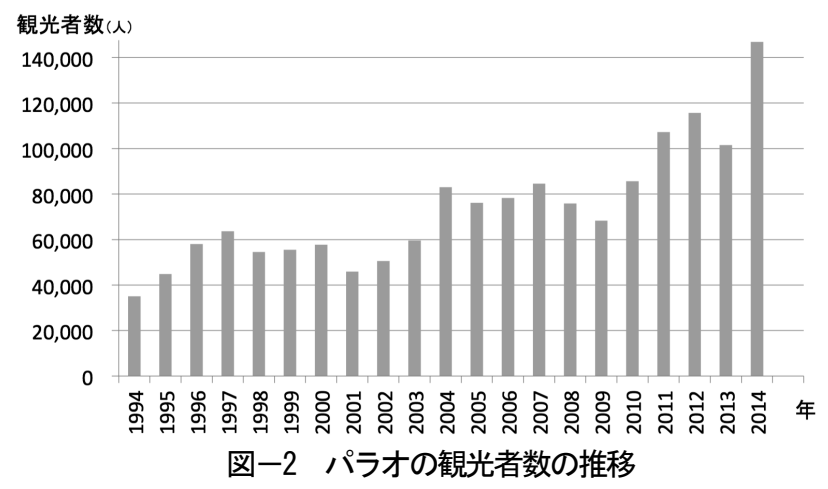

外国人観光者数は，パラオが独立した 1994 年時点では年間約 3.5 万人であったが，それ以降世界経済の影響を受けつつも年間 約 5 千人ずつのペースで増加し，2014 年には約 14.5 万人に達し た（図－2）6）２014 年の観光者のうち，日本人観光者数は 3 割 弱の約 3 万 8 千人であり，中国人観光者に次ぎ 2 番目に多い（図 -3）6）ただし，中国人観光者が日本人観光者数を上回ったのは 2014 年が初めてであり，2013 年までは，日本人観光者が最も多 い年が続いていた。日本人観光者にとって馴染みの観光地といえ, その上で環境負担金制度を既に実行しており，本研究課題を達成 するのに適した事例地であると判断できる。

\section{（2）パラオにおける環境負担金の種類}

パラオでは，観光者が中央政府に対して出国時に支払う環境税 (Environmental Protection Fee，通称 Green Fee）と州政府が 管理する各観光サイトで支払う入域料 (Entrance Fee または Permit）という 2 種類の環境負担金制度が存在する 7)。

中央政府が徵収する環境税はUS\$30 で，その内US $\$ 15$ が，中 央政府から各州政府に分配される自然保護基金（Protected Area Network Fund）の財源となり, 残り US $\$ 15$ は上下水道整備費 として使われる。

各州政府が徵収する入域料には，州の自然保護区や離島に入域 する際に支払うもの（Entrance fee）と, 定められた期間内の自 然保護区内での特定の行動を許可するもの (Permit) の 2 種類が ある。入域料の金額は，US $\$ 10$ から US $\$ 100$ まで州によって異 なる（表一1）。最も高いUS\$100 を徽収するのは，コロール州の ロックアイランドに入域し，中でもミズクラゲとタコクラゲの仲 間が生息する特別な塩湖に訪れるためのジェリーフィッシュレイ ク許可証である。ジェリーフィッシュレイクを除くその他のロッ クアイランドに入域する場合は, US $\$ 50$ ドルのロックアイランド 許可証が必要となる。コロール州は，増加する観光者による生態 系への影響を眯念し, 2000 年の許可証導入後に, 段階的な值上げ を実施している7)。その他の州では, ダイビングの許可証がUS\$10 $\sim 30$, 自然保護区や離島への入域料が US $\$ 10 \sim 15$ 程度で，コロ 一ル州と比較すると比較的安価な值段設定である。

なお, Permit は基本的にツアー事業者が州政府から事前に購入 しておき，観光者から代行して徴収するが，州政府からツア一事 業者への手数料はない。一方, Entrance fee はツア一事業者が代 行寸る場合と，自然保護区や離島に入域する際に個別に支払う場 合があり，州によって異なる。

\section{（3）調査紙調査の実施概要}

\section{1）調査項目}

調查項目は，同じ島嶼地域である沖縄県が実施している観光統 計実態調査 ${ }^{8)}$ と, 2014 年に Palau Visitors Authority (以下, PVA) が実施した観光者の動向調査 9)を参考にしたうえで，独自に環境 負担金についての学習方法，及ひ環境負担金を支払つたことに対 する貢献実感に関する項目を追加し，作成した。分析は，主に各 項目の単純集計と，項目相互間のクロス集計を実施した。また，

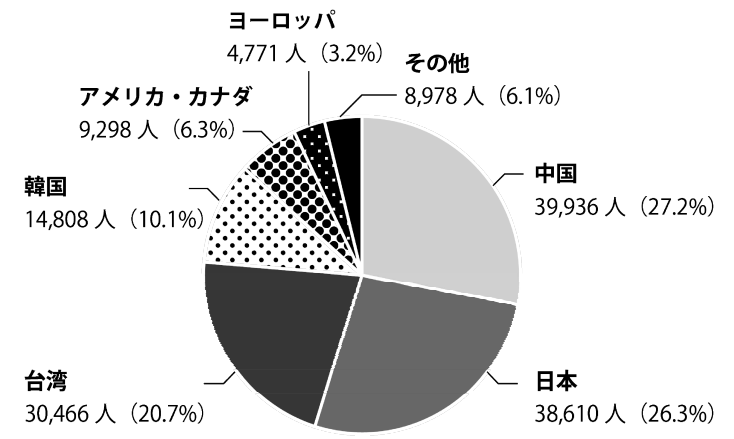

図-3 国・地域別の観光者数（2014 年）

\begin{tabular}{clcc} 
& 表一1 & パラオの主な環境負担金制度 & \\
\hline 所管 & & 環境負担金 & 金額 \\
\hline 中央政府 & 環境税 & & 有効期間 \\
\hline \multirow{2}{*}{ コロール } & ジェリーフィッシュレイク許可証 & 100 & - \\
州政府 & ロックアイランド許可証 & 50 & 10 日間 \\
& フィッシング許可証 & 20 & 10 日間 \\
ガラスマオ & ガラスマオの滝入域料 & 10 & 1 日間 \\
州政府 & ダイビング許可証 & 10 & - \\
\hline ペリリュー & ペリリュー島入域料 & 15 & 1 日間 \\
州政府 & ダイビング許可証 & 30 & 2週間 \\
\hline
\end{tabular}

差の検定は， $\chi^{2}$ 検定を実施した。

2）調査の実施方法

調査日は, 2015 年 3 月 18 日から 29 日の 12 日間である。調査 票の配布は, パラオのコロール国際空港において, 成田空港への 直行便の乗客に対して, 出国審査前に, 現地在住の調査協力者 2 名が搭乗者に直接手渡して行った。調査票の回収は，切手を貼っ た封筒を利用して帰国後にポストに投函する方法とインターネッ 卜を利用して回答寸る 2 種類の回答方法を選択できるようにした。 調查票の配布枚数は 500 通で，回収枚数は 2015 年 4 月 20 日 現在で郵送回答 214 通およびインターネット回答 6 通の合計 220 通（回数率 $44.0 \%$ ) となった（2015 年 4 月 5 日締切，最終到着 2015 年 4 月 20 日)。

\section{3. 結果}

\section{（1）回答者の基本属性および旅行特性}

表-2 に回答者の基本属性および旅行特性を示す。 50 代と 60 代が全体の半数を占めた。男女比はおお括ね半々であった。5 日 間の滞在が $68.3 \%$ と最も多い。初めてパラオを訪れる観光者は $47.5 \%$ と半数近いが，5 回以上の高頻度のリピーターも $28.3 \%$ 存 在した。なお，以上の本調査における回答者の基本属性と，パラ 才政府観光局の調查 9)によるパラオへの日本人旅行者の基本属性 を比較すると，その間に著しい偏りはないと判断された 10)。交通 費を含む旅行者一人あたり旅行予算額の平均 29.4 万円であり, 沖 縄県の平均旅行消費額 6.8 万円 ${ }^{11)}$ と比較すると, 約 4.3 倍と高額 な旅行であると言える。パラオ観光に対する観光者の満足度は, 10 点満点評価で, 平均 8.36 点であり, 満足度は高いことが示さ れた。旅行の種類は，フリープラン型パッケージが $68.8 \%$ と全体 の約 7 割を占め, 観光付きパッケージは $16.3 \%$, 個人旅行が $8.4 \%$, 団体旅行は $6.5 \%$ であった。フリープラン型パッケージと個人旅行 の観光者は, 現地の旅行会社が催行するツアー一選択的に参加し, 観光付きパッケージと団体旅行の観光者は，予め定められたツア 一に参加する。観光者が実施した活動は，ダイビングと水泳・シ ユノーケリングが半数以上を占めた（表一 3$)$ 。

\section{（2）環境負担金の支払額亡支払意思}

入域料の支払い先では，62.3\%がツア一事業者に支払っている ことが分かった（表一4）。そして，環境負担金に関する学習方法 
は，ガイドから受けることが多く，環境税で $69.8 \%$, 入域料で 45.1\%であった（表一5）。次に，雑誌や情報誌で自主学習寸る場 合が多く，環境税で $22.6 \%$, 入域料で $29.1 \%$ であった。一方，行 政の徵収担当者から説明を受けることは環境税で $4.2 \%$, 入域料で $1.9 \%$ と極端に少なく, 誰からも全く説明されなかった者も, 環境 税で $7.5 \%$, 入域料で $28.6 \%$ 存在した。

全体回答者 220 名のうち, 何らかの入域料を払った者は $93.6 \%$

表－2 回答者の基本属性および観光特性

\begin{tabular}{|c|c|c|c|}
\hline 項目 & カテゴリー & 人数 & 割合 \\
\hline 年齢 & 10 代 & 0 & $0.0 \%$ \\
\hline \multirow[t]{7}{*}{$(n=214)$} & 20 代 & 16 & $7.5 \%$ \\
\hline & 30 代 & 28 & $13.1 \%$ \\
\hline & 40 代 & 34 & $15.9 \%$ \\
\hline & 50 代 & 41 & $19.2 \%$ \\
\hline & 60 代 & 73 & $34.1 \%$ \\
\hline & 70 代 & 22 & $10.3 \%$ \\
\hline & 80 代以上 & 0 & $0.0 \%$ \\
\hline 性別 & 男 & 90 & $44.1 \%$ \\
\hline$(n=204)$ & 女 & 114 & $55.9 \%$ \\
\hline 住所 & 北海道·東北 & 12 & $5.8 \%$ \\
\hline \multirow[t]{4}{*}{$(n=207)$} & 関東 & 110 & $53.1 \%$ \\
\hline & 中部 & 66 & $31.9 \%$ \\
\hline & 近畿 & 8 & $3.9 \%$ \\
\hline & 中国·九州 & 11 & $5.3 \%$ \\
\hline 滞在日数 & 4日 & 14 & $6.4 \%$ \\
\hline \multirow[t]{4}{*}{$(n=219)$} & 5 日 & 143 & $65.3 \%$ \\
\hline & 6日 & 51 & $23.3 \%$ \\
\hline & 7-10日 & 8 & $3.7 \%$ \\
\hline & 11 日以上 & 3 & $1.4 \%$ \\
\hline パラオ来訪回数 & 初めて & 104 & $47.5 \%$ \\
\hline \multirow[t]{6}{*}{$(n=219)$} & 2 回目 & 30 & $13.7 \%$ \\
\hline & 3 回目 & 15 & $6.8 \%$ \\
\hline & 4 回目 & 8 & $3.7 \%$ \\
\hline & 5-9回目 & 36 & $16.4 \%$ \\
\hline & 10-19 回目 & 19 & $8.7 \%$ \\
\hline & 20 回目以上 & 7 & $3.2 \%$ \\
\hline 旅行の種類 & フリープラン型パッケージ & 148 & $68.8 \%$ \\
\hline \multirow[t]{3}{*}{$(n=215)$} & 観光付きパツケージ & 35 & $16.3 \%$ \\
\hline & 個人旅行 & 18 & $8.4 \%$ \\
\hline & 団体旅行 & 14 & $6.5 \%$ \\
\hline 旅行予算額 & 15 万円以下 & 8 & $3.7 \%$ \\
\hline (一人あたり) & 16 20 万円 & 37 & $17.1 \%$ \\
\hline \multirow[t]{8}{*}{$(n=217)$} & 21 25 万円 & 49 & $22.6 \%$ \\
\hline & 26〜30 万円 & 74 & $34.1 \%$ \\
\hline & 31 35 万円 & 21 & $9.7 \%$ \\
\hline & $36 \sim 40$ 万円 & 13 & $6.0 \%$ \\
\hline & 41 50 万円 & 8 & $3.7 \%$ \\
\hline & 51 万円以上 & 7 & $3.2 \%$ \\
\hline & 平均俌 & 29.4 & 万円 \\
\hline & 中央値 & 30.0 & 万円 \\
\hline 満足度 & 10 & 59 & $27.1 \%$ \\
\hline \multirow[t]{8}{*}{$(n=218)$} & 9 & 44 & $20.2 \%$ \\
\hline & 8 & 73 & $33.5 \%$ \\
\hline & 7 & 21 & $9.6 \%$ \\
\hline & 6 & 8 & $3.7 \%$ \\
\hline & 5 & 7 & $3.2 \%$ \\
\hline & 4 以下 & 6 & $2.8 \%$ \\
\hline & 平均値 & 8.353 & \\
\hline & 標準偏羞 & 1.505 & \\
\hline
\end{tabular}

表一3 実施した活動

\begin{tabular}{lcl}
\hline 実施した活動（複数回答可） & 人数 & 割合 \\
\hline ダイビング & 137 & $62.3 \%$ \\
水泳・シュノーケリング & 125 & $56.8 \%$ \\
買い物 & 65 & $29.5 \%$ \\
セイリング・カヤッキング & 41 & $18.6 \%$ \\
観光スポット巡り & 39 & $17.7 \%$ \\
戦跡への参拝·訪問 & 35 & $15.9 \%$ \\
滝ツアー & 31 & $14.1 \%$ \\
スパ・エステ & 28 & $12.7 \%$
\end{tabular}

その他（回答者の割合が 10\%未満の活動）

イルカ触れ合い体験，歴史·文化ツアー，ナイトツア一，遊覽飛行，釣り，

ハイキング・トレッキング, グラスボート・リバーボート

ウェディング・ハネムーン, アドベンチャースポーツ

注) 割合の母数 : $\mathrm{n}=220$

表-4 入域料の支払い先

\begin{tabular}{lrr}
\hline 支払先 & 人数 & 割合 \\
\hline ツア一事業者 & 137 & $62.3 \%$ \\
現地徵収者 & 47 & $21.4 \%$ \\
ダイビングショップ & 18 & $8.2 \%$ \\
州政府事務所 & 5 & $2.3 \%$ \\
ホテル & 3 & $1.4 \%$ \\
その他 & 5 & $2.3 \%$ \\
未回答 & 5 & - \\
\hline
\end{tabular}

注）割合の母数は、未回答を除く、 $\mathrm{n}=215$

表－5 環境負担金に関する学習方法

\begin{tabular}{lrrrr}
\hline & \multicolumn{2}{c}{ 環境税 } & \multicolumn{2}{c}{ 入域料 } \\
& 人数 & \multicolumn{1}{c}{ 割合 } & 人数 & \multicolumn{1}{c}{ 割合 } \\
\hline ガイドから説明を受けたた & 148 & $69.8 \%$ & 93 & $45.1 \%$ \\
杂謢・情報誌で自ら学んだ & 48 & $22.6 \%$ & 60 & $29.1 \%$ \\
行政 (徵収担当者)から説明を受けナた & 9 & $4.2 \%$ & 4 & $1.9 \%$ \\
説明されなかった & 16 & $7.5 \%$ & 59 & $28.6 \%$ \\
未回答・わからない & 8 & - & 14 & - \\
\hline
\end{tabular}

注）割合の母数は，未回答·わからないを除く，環境税 : n=212，入域料n=206

表一6 支払った入域料の種類と割合

\begin{tabular}{|c|c|c|}
\hline 入域料の名称 & 人数 & 割合 \\
\hline ジェリーフィッシュレイク許可証（\$100）※ & 81 & $36.8 \%$ \\
\hline ロックアイランド許可証（\$50）※ & 108 & $49.1 \%$ \\
\hline フィッシング・ライセンス（\$20） & 9 & $4.1 \%$ \\
\hline ペリリュー島ダイビング許可証（\$30） & 26 & $11.8 \%$ \\
\hline ガラスマオ州観光許可証（\$10） & 13 & $5.9 \%$ \\
\hline ペリリュー島入島税（\$10） & 41 & $18.6 \%$ \\
\hline その他 & 9 & $4.1 \%$ \\
\hline 未選択（支払っていない） & 14 & $6.4 \%$ \\
\hline 平均值 & & US\$69.7 \\
\hline 最大値 & & US $\$ 140.0$ \\
\hline 最小値 & & US $\$ 10.0$ \\
\hline
\end{tabular}

注）割合の母数は $n=220$

表-7 環境負担金への支払意思

\begin{tabular}{lrrrr}
\hline & \multicolumn{2}{c}{ 環境税 } & \multicolumn{2}{c}{ 入域料 } \\
& 人数 & 割合 & 人数 & 割合 \\
\hline 自然を守るためには仕方ない & 114 & $52.3 \%$ & 130 & $60.7 \%$ \\
税なので仕方ない & 59 & $27.1 \%$ & 40 & $18.7 \%$ \\
自然を守るためにぜひ支払いたい & 29 & $13.3 \%$ & 36 & $16.8 \%$ \\
もっと徵収すべきだ & 4 & $1.8 \%$ & 3 & $1.4 \%$ \\
わからない & 12 & $5.5 \%$ & 5 & $2.3 \%$ \\
未回答 & 2 & - & 6 & - \\
\hline
\end{tabular}

注1) 環境税: US $\$ 30$ 、入域料: US $\$ 10 \sim 100$

注2）割合の母数は未回答を除く，環境税 : $n=218$, 入域料 : $n=214$ 
を占めていた（表一6）。特に，コロール州のロックアイランド入 域料, またはジェリーフィッシュレイク許可証（ロックアイラン ド入域料が含まれる）のいずれかを支払った回答者は全体の 91.7\%であり，大多数が世界遺産であるロックアイランドへ訪れ るために入域料を支払っていた。また，支払つた入域料の平均值 はUS \$69.7 (約 8,294 円 12 ) ), 最大值がUS \$140(約 16,660 円 12)）であった（表一6）。環境税 US $\$ 30$ を加えると，約 US $\$ 100$ (約 11,900 円 12) ) を環境負担金として支払っているため，一人 あたりの旅行予算額のうち約 4\%を環境負担金として支払ってい ることになる。

この環境負担金の支払いに対する観光者の意識としては,「自然 を守るためには仕方がない」と回答した観光者が，環境税で $52.3 \%$ ，入域料で $60.7 \%$ と最も多く，「自然を守るためにぜひ支 払いたいりと回答した観光者も, 環境税で $13.3 \%$, 入域料で $16.8 \%$ 存在し, 概ね 7〜8 割の観光者が環境負担金の支払いを納得して いることが示された（表一7）。一方で，「税なので仕方がない」 という消極的な回答も, 環境税で $27.1 \%$, 入域料で $18.7 \%$ 存在し た。方，「もっと徵収すべきだ」という観光者は環境税で $1.8 \%$ 、 入域税で $1.4 \%$ にとどまった。

再来訪意向は，「同額の環境負担金を支払っても来たい」（表一 8 の質問 1）に対し，92.1\%が肯定的回答を示しており，内訳で は「そう思う」が $54.6 \%$ と最も多かった。また，環境負担金の支 払いを通じての「地域貢献」（表－8の質問 2) に対して肯定的回 答をした者は $68.4 \%$ ，「環境保全」（表－8の質問 3）に対し肯定 的回答をした者は $63.0 \%$ 存在した。しかし，その内訳では，「ど ちらかと言えばそう思う」という消極的な意見が最も多く，観光 者全体の 32.1\% (地域貢献)，36.6\% (環境保全) を占め，「やや そう思う」の $14.9 \%$ (地域貢献)， $15.7 \%$ (環境保全) や，「そう 思う」の $21.4 \%$ (地域貢献)，10.6\%（環境保全）を上回った。

また，環境負担金の支払いによる貢献実感度を 0 から 10 の 11 段階で問う質問に対して，尺度の中央に值寸る貢献実感度 5 の割 合が $28.1 \%$ と最も多く全体の約 4 分の 1 を占め, 続いて貢献実感 度 8 の観光者が $13.8 \%$, 貢献実感度 10 の観光者が $11.0 \%$ と続い た (表一9)。

なお，貢献実感度について，累積割合で下位 $25 \%$ 以下の層を 「低」グループ，上位 $25 \%$ 以上の層を「高」グループ，「低」お よび「高」に含まれない層を「中」グループとし，各グループの 貢献実感度は「低」が 0 から 4 , 「中」が 5 から 7 ,「高」が 8 か ら 10 と分類して, 以降の分析に用いた。

\section{(3) 支払限度額と実支払額の関係}

実際の支払額（以下，実支払額）と比べた支払限度額を，実支 払額を基淮にして，実支払額以上支払ってもよい (プラス)，同程 度（土0），実支払額を下回る（マイナス）の三段階に分けて集計 した結果を表一10 に示した。まず実支払額を元にした分類毎に,
支払限度額と実支払額の差を三段階に分けると，実支払額に対し ては, 同程度またはプラスの評価が多い傾向が示された。そして, 支払限度額の平均值はUS $\$ 77.5$ であり, 実支払額の平均US $\$ 69.7$ よりもUS $\$ 8$ 程度高かった。支払限度額の最大值も US $\$ 250$ とな り, 実支払額よりも高かった。一方で, 支払限度額を元に分類し, 支払限度額と実支払額の差を三段階に分けた場合, US $\$ 150$ 以上 の場合は全員がそれ以上支払いたくないというマイナスの評価を しており, US\$50未満の場合はもっと支払っても良いというプラ スの評価をしている傾向が示された。

\section{（4）支払意思および学習方法と貢献実感度との関係}

「支払限度額と実支払額の差」と貢献実感を縱横の軸にとって, 集計した結果を表一 11 に示した。表一11 を見ると，貢献実感度 が「低」「中」「高」の全てのグループで，同程度の支払い $( \pm 0)$ を望む回答者が 5 割程度と最も多くなっていることがわかった。 ここで「中」「高」グループに着目すると, 実支払い額よりもつと 支払ってもよい (プラス) という回答者が 3 割を超え，実支払い 額よりも低い金額しか払いたくない（マイナス）という回答者よ りも多かった。一方「低」グループは，実支払い額より低い金額 しか支払いたくない (マイナス) という回答者が 3 割弱を占め, 実支払い額よりもっと支払ってもよい（プラス）という回答者よ りも多かった。この結果より, 貢献実感度が高くなるとより環境 負担金をより支払ってもよいと考える人が増える傾向にあること が推測された。ただし，この結果を $\chi^{2}$ 検定で確認したところ， 「中」「高」と「低」の間に統計的に有意な差があるとは言えず, 今回の調査結果からだけでは，この傾向が明確であるとは言えな かったため，更なる調査が必要である。

次に，環境負担金に対する学習方法の違いと貢献実感を縦横の 軸にとって集計した結果を表一 12 に示した。空港で出国時に支払 う環境税に関しては，「低」グループは「説明されなかった」が 40.0\%と最も多く，「中」と「高」グループは「ガイドから説明を 受けた」がそれぞれ $50.5 \%$ と $44.8 \%$ 最も多く，「説明されなかっ

表一9 環境負担金に対する貢献実感度

\begin{tabular}{crrrrc}
\hline 貢献実感度 & 人数 & \multicolumn{1}{c}{ 割合 } & 累積割合 & \multicolumn{1}{c}{ グループ } \\
\hline 0 & 12 & $5.7 \%$ & $5.7 \%$ & & \\
1 & 8 & $3.8 \%$ & $9.5 \%$ & & 累積割合で、 \\
2 & 6 & $2.9 \%$ & $12.4 \%$ & 低 & 下位 $25 \%$ \\
3 & 20 & $9.5 \%$ & $21.9 \%$ & & \\
4 & 10 & $4.8 \%$ & $26.7 \%$ & & \\
\hline 5 & 59 & $28.1 \%$ & $54.8 \%$ & & 低およひ高に \\
6 & 18 & $8.6 \%$ & $63.3 \%$ & 中 & 含まれない層 \\
7 & 20 & $9.5 \%$ & $72.9 \%$ & & \\
\hline 8 & 29 & $13.8 \%$ & $86.7 \%$ & & 累積割合で、 \\
9 & 5 & $2.4 \%$ & $89.0 \%$ & 高 & 上位25\%以上層 \\
10 & 23 & $11.0 \%$ & $100.0 \%$ & & \\
\hline 未回答 & 10 & & & &
\end{tabular}

注) 割合の母数は未回答を除く, $\mathrm{n}=210$

\section{表-8 観光者の再来訪意向と地域振興 · 環境保全に対する貢献実感}

\begin{tabular}{|c|c|c|c|c|c|c|c|c|}
\hline & $\begin{array}{l}\text { そ } \\
\text { う } \\
\text { 思 } \\
\text { わ } \\
\text { な } \\
\text { い }\end{array}$ & $\begin{array}{l}\text { や } \\
\text { や } \\
\text { そ } \\
\text { j } \\
\text { 思 } \\
\text { わ } \\
\text { な } \\
\text { い }\end{array}$ & $\begin{array}{c}\text { そど } \\
\text { うち } \\
\text { 思ら } \\
\text { わか } \\
\text { なと } \\
\text { い言 } \\
\text { え } \\
\text { ば }\end{array}$ & $\begin{array}{c}\text { そ ど } \\
\text { う } \\
\text { 思ら } \\
\text { うか } \\
\text { と } \\
\text { 言 } \\
\text { え } \\
\text { ば }\end{array}$ & $\begin{array}{l}\text { そや } \\
\text { jや } \\
\text { 思 } \\
\text { j }\end{array}$ & $\begin{array}{l}\text { そ } \\
\text { j } \\
\text { 思 } \\
\text { j }\end{array}$ & $\begin{array}{l}\text { 否 } \\
\text { 定 } \\
\text { 的 } \\
\text { 回 } \\
\text { 答 }\end{array}$ & $\begin{array}{l}\text { 肯 } \\
\text { 定 } \\
\text { 的 } \\
\text { 回 } \\
\text { 答 }\end{array}$ \\
\hline 質問1) 同額の入域税·環境税等を支払っても、またパラオに来たい(再来訪意向） & $2.8 \%$ & $1.9 \%$ & $3.2 \%$ & $20.4 \%$ & $17.1 \%$ & $54.6 \%$ & $7.9 \%$ & $92.1 \%$ \\
\hline 質問3) 入域税·環境税等の仕組みによりパラオの環境は適切に保全されると感じた(環境保全) & $8.3 \%$ & $9.3 \%$ & $19.4 \%$ & $36.6 \%$ & $15.7 \%$ & $10.6 \%$ & $37.0 \%$ & $63.0 \%$ \\
\hline
\end{tabular}

注1) 否定的回答とは,「そう思わない」ややそう思わない」「どちらかと言えばそう思わない」の回答者の合計を示す。

注2) 肯定的回答とは,「そう思う」やややう思う」「どちらかと言えばそう思う」の回答者の合計を示す。

注3)各割合の母数は未回答を除く, 質問1)はn=216、質問2)はn=215、質問3)はn=216である

注4) 塗りつぶしは最も人数の多いカテゴリーを示す 
表-10 支払限度額と実支払額の関係

\begin{tabular}{|c|c|c|c|c|c|c|c|c|}
\hline & & \multicolumn{4}{|c|}{ 人数 } & \multicolumn{3}{|c|}{ 割合 } \\
\hline & & マイナス & \pm 0 & プラス & 合計 & マイナス & \pm 0 & プラス \\
\hline 環境税 & $\$ 30$ & 37 & 90 & 62 & 189 & $19.6 \%$ & $47.6 \%$ & $32.8 \%$ \\
\hline \multirow{6}{*}{ 実支払額(入域料) } & \$50未満 & 1 & 12 & 13 & 26 & $3.8 \%$ & $46.2 \%$ & $50.0 \%$ \\
\hline & $\$ 50-74$ & 16 & 49 & 23 & 88 & $18.2 \%$ & $55.7 \%$ & $26.1 \%$ \\
\hline & $\$ 75-99$ & 6 & 6 & 7 & 19 & $31.6 \%$ & $31.6 \%$ & $36.8 \%$ \\
\hline & $\$ 100-119$ & 19 & 35 & 19 & 73 & $26.0 \%$ & $47.9 \%$ & $26.0 \%$ \\
\hline & $\$ 120$ 以上 & 1 & 6 & 2 & 9 & $11.1 \%$ & $66.7 \%$ & $22.2 \%$ \\
\hline & 合計 & 43 & 108 & 64 & 215 & & & \\
\hline \multirow{6}{*}{ 支払限度額 } & \$50未満 & 6 & 12 & 22 & 40 & $15.0 \%$ & $30.0 \%$ & $55.0 \%$ \\
\hline & $\$ 50-99$ & 16 & 55 & 21 & 92 & $17.4 \%$ & $59.8 \%$ & $22.8 \%$ \\
\hline & $\$ 100-149$ & 21 & 41 & 0 & 62 & $33.9 \%$ & $66.1 \%$ & $0 \%$ \\
\hline & $\$ 150-199$ & 12 & 0 & 0 & 12 & $100 \%$ & $0 \%$ & $0 \%$ \\
\hline & $\$ 200$ 以上 & 9 & 0 & 0 & 9 & $100 \%$ & $0 \%$ & $0 \%$ \\
\hline & 合計 & 64 & 108 & 43 & 215 & & & \\
\hline
\end{tabular}

注1) 支払限度額の平均值: $\$ 77.5$ 、最大值: $\$ 250$ 、最小值: $\$ 10$ 、最頻值 : $\$ 50$

注2) マイナス: 支払限度額<実際の支払額、士0: 現状の支払額が適当 (不明とする回答者数も含む)、プラス: 支払限度額 $>$ 実際の支払額 注3)塗りつぶしは最も人数の多いカテゴリーを示す

\section{表一11 支払意思と貢献実感度の関係}

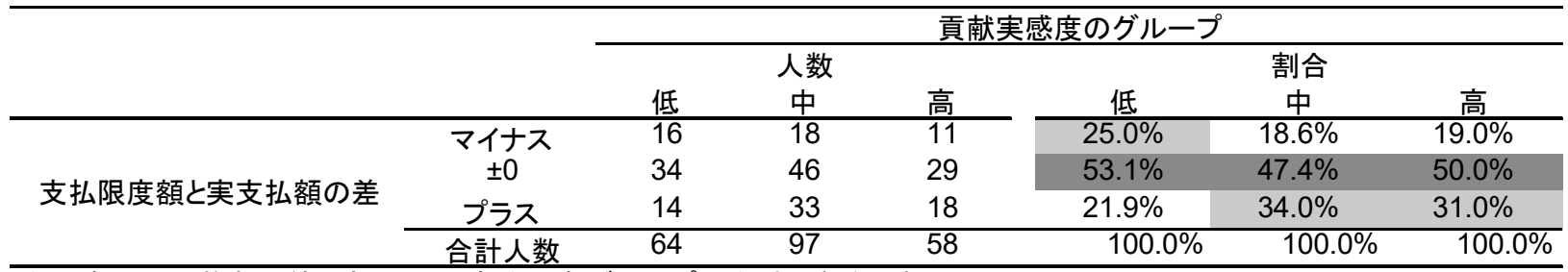

注1) 各質問は複数回答であるため、割合は各グループの合計人数を母数としている

注2) 濃い塗りつぶしは最も高い割合を示し、薄い塗りつぶしは2番目に高い割合を示す

\section{表-12 学習方法と貢献実感度の関係}

\begin{tabular}{|c|c|c|c|c|c|c|c|c|}
\hline & & & \multicolumn{6}{|c|}{ 貢献実感度のグループ } \\
\hline & & & \multicolumn{3}{|c|}{ 人数 } & \multicolumn{3}{|c|}{ 割合 } \\
\hline & & & 低 & 中 & 高 & 低 & 中 & 高 \\
\hline \multirow{9}{*}{ 学習方法 } & \multirow{4}{*}{ 環境税 } & ガイドから説明を受けた & 6 & 49 & 26 & $9.2 \%$ & $50.5 \%$ & $44.8 \%$ \\
\hline & & 行政（徵収担当者）から説明を受けた & 0 & 3 & 1 & $0.0 \%$ & $3.1 \%$ & $1.7 \%$ \\
\hline & & 説明されなかった & 26 & 25 & 8 & $40.0 \%$ & $25.8 \%$ & $13.8 \%$ \\
\hline & & 雑誌·情報誌で自ら学んだ & 17 & 21 & 22 & $26.2 \%$ & $21.6 \%$ & $37.9 \%$ \\
\hline & \multirow{5}{*}{ 入域料 } & ガイドから説明を受けた & 36 & 75 & $\overline{37}$ & $55.4 \%$ & $77.3 \%$ & $63.8 \%$ \\
\hline & & 行政(徵収担当者)から説明を受けた & 6 & 3 & 0 & $9.2 \%$ & $3.1 \%$ & $0.0 \%$ \\
\hline & & 説明されなかった & 9 & 3 & 4 & $13.8 \%$ & $3.1 \%$ & $6.9 \%$ \\
\hline & & 雑誌·情報誌で自ら学んだ & 13 & 16 & 19 & $20.0 \%$ & $16.5 \%$ & $32.8 \%$ \\
\hline & & 合計人数 & 64 & 97 & 58 & $100.0 \%$ & $100.0 \%$ & $100.0 \%$ \\
\hline
\end{tabular}

注1) 各質問は複数回答であるため、割合は各グループの合計人数を母数としている

注2) 濃い塗りつぶしは最も高い割合を示し、薄い塗りつぶしは2番目に高い割合を示す

た」はそれぞれ $25.8 \%$ と $13.8 \%$ と「低」グループより顕著に少な かった。一方，ツアー参加時に支払うことが多い入域料に関して は，「低」「中」「高」いずれのグループも「ガイドから説明を受け た」といら割合が高かった。さらに，ここで「雑誌・情報誌で自 ら学んだ」といら項目に着目すると, 環境税については「高」グ ループの $37.9 \%$ 自主学習によって理解しているが，「低」と

「中」グループではそれぞれ $26.2 \%, 21.6 \%$ にとどまった。入域 料の場合も，「高」グループで，32.8\%が自主学習により理解し， 「低」と「中」グループではそれぞれ $20.0 \%$ と $16.5 \%$ と，同様の 傾向が示された。ただし，自主学習と環境税・入域料の関係につ いて $x^{2}$ 検定を行ったところ，「高」グループと「中」グループの 間は $5 \%$ で統計的に有意と判定されたが，「高」グループと「低」 グループの間は有意であると判定されなかった。自主学習により 貢献実感が増加するかどうかについて，今後より詳細な調査・検 討が必要である。

\section{4. まとめと考察}

\section{（1）環境負担金に対する支払い意思と貢献実感の関係}

パラオにおける日本人観光者への環境負担金に対する支払意思 とその支払に対する貢献実感に関する調査紙調査により，以下の ことが明らかとなった。

第一に，環境負担金の支払い金額について，日本人観光者は， 環境負担金としてUS $\$ 50$ (約5,950円 12 ) 加 US $\$ 150$ (約 17,850 円 12)）の範囲での支払いを許容しており，平均は約US $\$ 100$ (約 11,900 円 12)) であった。また, 約 9 割の観光者は同額を支払った としてもパラオへの再来訪意向があることがわかった。さらに, 環境負担金の支払いによる環境保全や地域社会への貢献実感度が 高い観光者の方が，より多くの環境負担金を受容する傾向が明ら かとなった。

第二に，環境負担金の支払いについて，観光者の約 7〜8 割が 
肯定的な回答をしており, 制度に対して一定の理解があることが わかった。一方で，環境負担金の支払いに対する貢献実感は，肯 定的意見が全体の 6〜 7割を占めるものの, そのうち 3〜 4割は「ど ちらかと言えばそう思う」と消極的な意見であり，観光者は十分 に貢献実感を得られていないことが明らかとなった。

第三に, 環境負担金に関する学習方法について,「説明を受けな かった」者や「ガイドから説明を受けた」者は，「雑誌や情報誌で 自ら学んだ」者より, 貢献実感度が低い傾向が見られた。ガイド が政府機関との代わりに環境負担金を徵収するため，金額や制度 の概要を説明する機会があることは現地調查で確認できた。しか し，環境負担金の使い道に関する説明をガイドから十分にする時 間や義務がないため,「ガイドから説明を受けた」者の貢献実感度 が低いままであると考えられる。

以上の結果より，観光者の環境負担金の支払いに対する貢献実 感を高めることが，支払いに対する肯定的な意識や態度に影響を 与えており, さらに，観光者の貢献実感を高めるためには，雑誌 や情報誌等で観光者が自主学習寸る機会を提供することが重要で あることが示唆された。収集した環境負担金の用途を開示するだ けでなく, 環境負担金による地域貢献や環境保全への効果を伝え るといった環境負担金制度に対する理解を高める仕組みづくりが, 観光者の環境負担金の支払い意思を高める上で重要な点であると いえる。そして，パラオにおける実施した活動の上位にダイビン グやシュノーケル, カヤックなどガイドが同行するツアーが位置 していることから，ガイドが丁寧に説明する仕組みは環境負担金 への理解を深める上で効果的であると考えられる。

\section{（2）我が国の環境負担金制度に対する示唆}

パラオにおいては, 日本人観光者の 7〜8 割が環境負担金を肯 定的に捉え，か数千円から 1 万円以上という高額の環境負担金 を支払っていても再来訪意向を持っている。これまで我が国で実 施されてきた環境負担金は, 観光者数が減少することの彩念から, 概ね 100 円から 1,000 円程度と低額に設定されていた 1$)$ が，本研 究の結果は日本人観光者も高額の環境負担金を許容できることを 示唆するものである。特に, 富士山では 7,000 円程度の環境負担 金を徵収しなければ観光者数を抑制できないという研究結果 2)も あり，金額だけで言えば，観光者にとっては支払い可能な範囲で あることを示唆している。身近な国内旅行と，特別な海外旅行と いう違いはあるにせよ，支払いに見合った満足度と貢献実感が得 られる場所であれば，現在よりも高額の環境負担金を導入するこ とを検討する余地は十分にあると考えられる。

また，我が国は徵収者を自治体が雇用する場合が多く，その人 件費が課題となり環境負担金制度を導入できないことが指摘され ている 2)。一方，パラオではツアー事業者が環境負担金の徵収業 務を代行することで，州政府が徵収者を雇用せずとも，確実に環 境負担金を徵収する仕組みが成り立っている。我が国においても ツアー事業者等との連携による環境負担金の徵収を検討するため の参考になると考えられる。

また，環境負担金制度は，ただ単に自治体が自然観光地の管理 費用を調達する仕組みや, 観光者数の抑制をはかる仕組みとして だけでなく，観光者がその支払いを通して環境保護や地域社会一 の貢献を実感し，意識を高める上で有効なものである。環境負担 金の金額や運用方法の検討を進めることと合わせて，我が国の観 光者が，より責任ある観光行動をとれるよう，観光に際する倫理 観を醸成していくことも社会的課題であると言える。

謝辞: 本研究は, 環境研究総合推進費 (4RF-1401) の助成を受け たものです。アンケート調査実施に際し，パラオ在住の Lolita Gatuz 氏と Marasigan Chacha 氏に協力を頂きました。また, Palau Visitors Authorityの Nanae Singeo 氏には快くデータを
提供して頂きました。調査データの分析においては，東京大学大 学院の濱泰一氏に協力を得ました。ここに皆さまへの謝意を申し 上げます。

\section{補注及び引用文献}

1） 中野かおり (2014) 入域料, ナショナル・トラスト活動の法 定化一地域自然資産区域における自然環境の保全及び持続 可能な利用の推進に関する法律案. 立法と調查 356, 68-76

2）公益財団法人日本交通公社 (2015) 特集 入山料を問う, 観 光文化，226，2-45

3）栗山浩一（2013）富士山入山料の効果について. http://www.kyoto-u.ac.jp/static/ja/news_data/h/h1/news6/2 013/130604_1.htm（2013/06/04 更新，2014/09/24 参照)

4）栗山浩一 (2015) データに基づいた富士山入山料の多角的分 析，観光文化，226，15-18

5) Bureau of Budget and Planning, Ministry of Finance (2013) 2013 Statistical Yearbook. 12pp

6）観光者数の推移は，Palau Visitors Authority より提供を受 けた観光統計資料 (非公開) による

7）飯田晶子・武正憲（2015）パラオ共和国における観光振興と 調和した自然保護政策の展開に関する研究, ランドスケープ 研究 78(5)，p783-786

8）沖縄県文化観光スポーツ部（2013）平成 24 年度観光統計実 態調査, $115 \mathrm{pp}$

9) South Pacific Tourism Organisation (2014) Palau tourist survey, 144pp

10）パラオ政府観光局が実施した 2014 年の調査によれば，パラ 才日本観光者全体の年齢構成は，0-18 歳が $5.8 \%, 19-44$ 歳 が 80.0\%，45-64 歳が $12.8 \% ， 65$ 歳以上が $1.3 \%$ である。 方，本調査結果は，10 代と 20 代を合わせて $7.5 \% ， 30$ 代と 40 代を合わせて $29.0 \% ， 50$ 代と 60 代を合わせて $53.3 \%$, 70 代以上が $10.3 \%$ である。本調査の回答者の方が高齢者の 割合は高いが, いずれの調査も 20 代から 60 代までが少なく とも全体の 8 割を占めるので, 回答者に著しい偏りはないと 判断した。

11）沖縄県文化観光スポーツ部（2014）平成 25 年度観光統計実 態調査, $105 p p$

12） 2015 年 3 月末の為替レート US $\$ 1=$ 約 119 円で計算 